\title{
Reliability and validity of a Portuguese version of the Young Mania Rating Scale
}

\section{J.A.A. Vilela, \\ J.A.S. Crippa, \\ C.M. Del-Ben and \\ S.R. Loureiro}

\author{
Departamento de Neurologia, Psiquiatria e Psicologia Médica, \\ Faculdade de Medicina de Ribeirão Preto, Universidade de São Paulo, \\ Ribeirão Preto, SP, Brasil
}

\begin{abstract}
Correspondence
J.A.A. Vilela

Departamento de Neurologia,

Psiquiatria e Psicologia Médica

FMRP, USP

Av. Bandeirantes, 3900

14049-900 Ribeirão Preto, SP

Brasil

Fax: +55-16-602-2544

E-mail: vilela@rnp.fmrp.usp.br

J.A.A. Vilela was the recipient of

a fellowship from FAPESP (No.

97/14455-5). J.A.S. Crippa is the

recipient of a CAPES (Programa de

Absorção Temporária de Doutores,

Prodoc No. 16/2003, 2003-2004)

fellowship.
\end{abstract}

Received June 30, 2004

Accepted May 20, 2005

Abstract

The reliability and validity of a Portuguese version of the Young Mania Rating Scale were evaluated. The original scale was translated into and adapted to Portuguese by the authors. Definitions of clinical manifestations, a semi-structured anchored interview and more explicit rating criteria were added to the scale. Fifty-five adult subjects, aged 18 to 60 years, with a diagnosis of Current Manic Episode according to DSM-III-R criteria were assessed using the Young Mania Rating Scale as well as the Brief Psychiatric Rating Scale in two sessions held at intervals from 7 to 10 days. Good reliability ratings were obtained, with intra-class correlation coefficient of 0.97 for total scores, and levels of agreement above $0.80(\mathrm{P}<0.001)$ for all individual items. Internal consistency analysis resulted in an $\alpha=0.67$ for the scale as a whole, and an $\alpha=0.72$ for each standardized item ( $\mathrm{P}$ $<0.001$ ). For the concurrent validity, a correlation of 0.78 was obtained by the Pearson coefficient between the total scores of the Young Mania Rating Scale and Brief Psychiatric Rating Scale. The results are similar to those reported for the English version, indicating that the Portuguese version of the scale constitutes a reliable and valid instrument for the assessment of manic patients.

\section{Introduction}

Several mania rating scales have been developed and tested over the last three decades (1-8). The most frequently used one in controlled studies is the Young Mania Rating Scale (YMRS), because of its high reliability and validity coefficients (5). As a result, the YMRS is often used as a reference for the concurrent validation of other instruments (7-13).

In spite of this, the YMRS has some limitations, such as the absence of precise definitions of the items evaluated. Without operational definitions, each evaluator uses
Key words

- Mania

- Rating scales

- Reliability

- Validity

- Brief Psychiatric Rating Scale ..................... his/her previous experience with psychopathology as a reference point to define the item evaluated, impairing the reliability between evaluators. Furthermore, there is no systematic procedure for data collection with the YMRS. Structured interviews or interview guidelines may be particularly useful for individual evaluators and/or evaluators without extensive training in the recognition and conceptualization of psychopathology (14).

Although most of the controlled studies with manic patients use the YMRS, there are several studies that do not utilize a specific scale for mania or associate a standardized 
instrument with another one for the rating of severity of symptoms, such as the Brief Psychiatric Rating Scale (BPRS) (15) and the Clinical Global Impression (16). This suggests that mania rating scales are not as good as the scales developed for other psychiatric disorders $(5,17,18)$ and highlights the need for studies of the psychometric qualities of available mania scales, as well as for the development of better instruments.

The importance of this work becomes clear when one considers that Bipolar Disorder is one of the most prevalent and disabling mental disorders (17), and new drug development requires sensitive and reliable instruments. In particular, a systematically validated instrument for the assessment of the severity of manic symptoms is not available in Portuguese-speaking countries. As a consequence, the purpose of the present study was to translate the English version of YMRS into Portuguese and to assess the reliability and validity of the Portuguese version.

\section{Subjects and Methods}

\section{Translation and adaptation of the Young Mania Rating Scale}

Three researchers independently translated the YMRS into Portuguese from its original English version and the different versions were discussed and compared. A final version was obtained, back translated and compared to the original scale in English. The conclusion was that there were no relevant differences in the content of the two versions of the scale.

Some modifications were made in order to adapt the instrument for systematic application based on operational definitions. A glossary of definitions for identifying the manifestations observed was introduced to improve precision in their observation and reporting. Each item of the scale was defined according to signs and symptoms described by Kaplan and Sadock (19) and presented in the Diagnostic and Statistical Manual of Mental Disorders, 4th edition (DSM-IV) (20).

To facilitate and systematize the application of the rating scale, a semi-structured interview outline was formulated with guidelines for questions. These were based on questions used for the assessment of other instruments already standardized for the Portuguese language $(21,22)$. The aim was to provide elements that would allow the assessment of the severity of each item of the scale at the end of the interview.

An introduction containing explicit comments on the methodology used in the interview and instructions on how to codify the scale were developed to provide information about the codification procedure.

Finally, changes were made in the description of operational definitions of the levels of severity to better clarify the baseline criteria for distinguishing one degree from the other.

The Portuguese version of the Young Mania Rating Scale was named "Escala de Avaliação de Mania" (EAM) and its final version is presented in Appendix 1.

\section{Subjects}

Fifty-five patients (31 females and 24 males) aged 18 to 60 years (mean \pm SD: 32.2 \pm 10.9 ) took part in the study. The diagnosis of Bipolar I Disorder, current manic episode, was confirmed using the Portuguese version (21) of SCID for DSM-III-R (23). Patients were hospitalized in the psychiatric unit of the University Hospital, Faculty of Medicine of Ribeirão Preto and/or in the Psychiatric Hospital Santa Tereza.

The experimental protocol was approved by the Hospital Ethics Committee and each patient plus one of his/her relatives signed an informed consent form.

\section{Evaluators}

Seven psychiatrists took turns in differ- 
ent rating pairs. Training started with joint reading of the instrument, followed by explanation and discussion about the recording protocol and the list of operational definitions of the manifestations to be observed. Then, for training purposes, interviews with non-subject manic patients were recorded on videotape. The group of evaluators watched the recorded interviews and each one rated the patients independently. For each interview, the scores of the individual items of the scale were compared and the differences between evaluators were identified and discussed. This procedure was repeated until the evaluators reached a minimal agreement of $70 \%$ on individual items of the scale in three consecutive and independent ratings.

Finally, individual ratings with the EAM were performed. They consisted of a live interview with a manic patient held by one of the evaluators and observed by one of the authors of this study, followed by calculation of the agreement index.

\section{Data collection}

During the initial $48 \mathrm{~h}$ of hospitalization, the patients who fulfilled the inclusion criteria were rated with the EAM and the BPRS Bech's version (24) translated and validated into Portuguese (25). In this version of the BPRS, items are rated within 5 levels of severity (0 to 4). The interview for grading the EAM and the BPRS, which lasted 15 to $30 \mathrm{~min}$, was performed by one of the evaluators and observed by another. Soon after, each participating evaluator independently completed the scales. Evaluators were instructed not to exchange information until the end of the study.

\section{Statistical analysis}

Data were analyzed statistically with the SPSS for Windows software, version 6 (SPSS Incorporation, 1989-1993). The inter-rater reliability coefficient for individual and total scores of the EAM was calculated using the intra-class correlation coefficient (26), which is considered to be the most appropriate measure to assess reliability between evaluators (27).

Internal consistency was assessed by Cronbach's $\alpha$. The Pearson correlation coefficient was employed to evaluate the concurrent validity of individual and total scores of the EAM and the BPRS. Wilcoxon's proof was used to assess the EAM sensitivity to alterations in the severity of symptoms in the same individual between the first and second rating (differences observed after 7 to 10 days). The Pearson moment-product correlation coefficient $r$ was employed to determine the concurrent validity of the EAM with the BPRS. A correlation was taken to be significant at the level of $\mathrm{P} \leq 0.05$.

\section{Results}

Ninety-three paired ratings were analyzed to determine the EAM inter-rater reliability indices. They resulted in 186 completed protocol sets, 106 from the first evaluation and 80 from the second.

Table 1 shows the values of the intraclass correlation coefficient for the individual items and for the total score of the EAM. Levels of agreement above $0.80(\mathrm{P}<0.001)$ were obtained for all the individual items and for the final scores in the two evaluations. In the second rating, the agreement indices were slightly better than the first rating for the total score as well as for individual items, except for items 1 (Elevated mood), 3 (Sexual interest), 6 (Speed and amount of speech), and 10 (Appearance).

Cronbach's $\alpha$ was calculated using analysis of variance applied to the eleven items of the scale for the 55 subjects for internal analysis of consistency. From the resulting co-variance matrix, an $\alpha=0.67$ was obtained for the scale as a whole and an $\alpha=0.72$ for each standardized item $(\mathrm{P}<0.001)$. Most of the 
items correlated well with one another as well as with the total score, so that their removal would reduce the internal consistency of the instrument. However, this does not apply to three of the items - thought content, irritability and insight - which in this order were responsible for the progressive decrease of internal consistency. If only the thought content item were removed, Cronbach's $\alpha$ would be equal to 0.72 and $\alpha$ for standardized items would be equal to 0.74 . If two items - thought content and irritability - were removed, there would be $\alpha=0.73$ for the scale and $\alpha=0.74$ for standardized items. Finally, if the three items thought content, irritability and insight - were removed, there would be $\alpha=0.76$ for the scale and $\alpha=0.76$ for the standardized items.

Table 1. Inter-rater agreement through the "Escala de Avaliação de Mania" (EAM) intra-class correlation coefficient (ICC).

\begin{tabular}{lcc} 
Items & 1st Rating $^{*}(\mathrm{~N}=53)$ & 2nd Rating $^{*}(\mathrm{~N}=40)$ \\
\hline 1. Elevated mood & 0.95 & 0.93 \\
2. Increased activity and energy & 0.81 & 0.94 \\
3. Sexual interest & 0.96 & 0.96 \\
4. Sleep & 0.98 & 0.99 \\
5. Irritability & 0.92 & 0.93 \\
6. Speech (speed/amount of) & 0.91 & 0.87 \\
7. Language-thought disorder & 0.84 & 0.95 \\
8. Thought contents & 0.83 & 0.95 \\
9. Aggressive and disruptive behavior & 0.99 & 1.00 \\
10. Appearance & 0.94 & 0.90 \\
11. Insight & 0.90 & 0.98 \\
Total score & 0.95 & 0.97
\end{tabular}

*Levels of acceptance (26): ICC >0.75 - excellent agreement.

Table 2. Pearson's correlation coefficient ( $r$ ) between "Escala de Avaliação de Mania" (EAM) items and specific Brief Psychiatric Rating Scale (BPRS) items related to manic symptoms $(P<0.0001)$.

\begin{tabular}{llc}
\hline EAM item & BPRS item & $r$ \\
\hline Increased activity and energy & Motor hyperactivity & 0.728 \\
Irritability & Hostility & 0.499 \\
& Uncooperativeness & 0.583 \\
Speech (speed/amount of) & Motor hyperactivity & 0.598 \\
Language-thought disorder & Conceptual disorganization & 0.659 \\
Thought contents & Grandiosity & 0.767 \\
Aggressive and disruptive behavior & Uncooperativeness & 0.617 \\
\hline
\end{tabular}

To determine the concurrent validity, the correlation between the individual items and the total score of the EAM with the individual items and the total score of BPRS applied to the 55 subjects was calculated. To this end, bivariate correlation measurements between the two instruments were made using Pearson's moment-product correlation coefficient $r$. All the individual EAM items presented significant correlation at the level of $\mathrm{P}<0.05$ with at least one BPRS item. Item number 6 - Speech (speed and amount) was the EAM item which correlated more often with most of the BPRS items (11 items), while item 3 (Sexual interest) and item 4 (Sleep) correlated with only three BPRS items. As to the correlation of the BPRS items, it was observed that item 2 - Psychic anxiety, item 13 - Psychomotor retardation and item 16 - Blunted or inappropriate affect - did not significantly correlate with any EAM item.

BPRS is a scale designed to evaluate psychotic patients, mostly schizophrenics. However, five of its items measure severity of symptoms frequently seen in manic patients. In the present study, these items presented a high correlation with six EAM items, as shown in Table 2.

All the individual EAM items presented a significant correlation $(\mathrm{P} \leq 0.05)$ with the BPRS total score, except for item 4 (Sleep) and item 11 (Insight). The same happened with the BPRS individual items as related to the EAM total score, except for item 2 (Psychic anxiety), item 5 (Self-depreciation and guilt feelings), item 6 (Somatic anxiety), item 9 (Depressed mood), item 13 (Psychomotor retardation), and item 16 (Blunted or inappropriate affect). There was a high correlation between the two scales $(\mathrm{r}=0.78 ; \mathrm{P}=$ $0.0001)$ with respect to the total scores.

\section{Discussion}

The overall results obtained in the present study show better reliability levels than 
those obtained in the original study (5). This improvement is likely to be due to the adaptations of the rating protocol, such as adding the glossary of operational definitions describing the terminology of the scale more clearly and allowing more precise discrimination between the severity levels, making them more compatible with current concepts of mania. Moreover, the structured interview with guideline questions standardized the way information was obtained, minimizing the variability of interpretation among the different evaluators. Similar results have been reported by Williams with Hamilton's Depression Scale (28), by Lindström et al. (29) with the Positive and Negative Syndrome Scale and by Crippa et al. (22) with the BPRS. In the current study we could confirm that more structured instruments increase agreement levels, because even though most of the evaluators had little clinical experience, good reliability indices were achieved.

The validity indices achieved in the present study indicate that the EAM can measure severity levels of mania. The present values of the correlation indices between individual items and total scores are similar to those reported in previous studies on the psychometric qualities of mania rating instruments $(1-5,8)$.

The lack of a mania rating instrument validated in Portuguese for standard comparisons limits the present analysis of the concurrent validity of the EAM. Nevertheless, good correlation indices between EAM and BPRS items were obtained, particularly those more specifically pertinent to mania symptoms.

From a theoretical point of view, five BPRS items related to the manic symptoms described by DSM-IV (20) and ICD-10 (30) were identified, presenting a significant correlation with the scale total score. Considering these five items as a BPRS subscale, a strong correlation was found between the EAM individual items and the total score, in contrast to the other BPRS items, indicating the EAM specificity for rating manic symptoms. The correlation coefficient between the EAM total score and the BPRS total score $(r=0.78)$ was similar to the correlation indices reported with the BMSRS (1), YMRS (5) and CARS-M (8).

In the present study, changes to the YMRS (5) were made in order to minimize the shortcomings of the original scale, such as the absence of operational definition of the evaluated items and of a systematic procedure to collect data. The results discussed above show that this aim was achieved without changing the rating procedure, damaging the structural coherence of the instrument or adding time for its administration. Therefore, the EAM structure specifically takes into account the range of behavioral manifestations of the manic episode, using a relatively streamlined rating procedure.

Since this sample had only patients with severe mania, it was not possible to determine whether the EAM applies to hypomania or to manic patients with either mild or moderate symptoms. In the same way, it was not possible to establish whether the instrument can distinguish mania from other psychiatric disorders, particularly schizophrenia and other psychotic disorders.

Because the study was conducted without specifying the type of treatment or its duration, it became difficult to assess systematically the evolution of symptoms or to proceed to the longitudinal follow-up of the patient-subjects for a longer period of time. Thus, it was not possible to establish a cutoff EAM criterion predictive of either discharge or change in treatment modality.

EAM is the first instrument intended specifically for manic patients that has been adapted to the Portuguese language and subsequently validated by empirically studying its psychometric properties. The instrument shows high reliability and validity indices comparable to those previously reported with the use of similar instruments in the English language 
(1-8,10,13,31-33). The EAM is an instrument that can be easily applied and requires little training for its correct use. The use of a semistructured interview with guideline questions together with detailed operational definitions seems to have improved the instrument's reliability. As a result, the EAM may be used for assessing the severity of manic symptoms as well as to measure the efficacy of psychological and/or pharmacological treatment.

\section{Acknowledgments}

The authors are very grateful to Prof. Frederico Guilherme Graeff for his comments and suggestions in the revision of the manuscript, and to Mr. Dennis Farqharson for revising the English text.

\section{References}

1. Beigel A, Murphy DL \& Bunney WE (1971). The Manic-State Rating Scale: scale construction, reliability and validity. Archives of General Psychiatry, 25: 256-262.

2. Petterson U, Fyrö B \& Sedvall G (1973). A new scale for the longitudinal rating of manic states. Acta Psychiatrica Scandinavica, 49: $248-256$.

3. Blackburn IM, Loudon JB \& Ashworth CM (1977). A new scale for measuring mania. Psychological Medicine, 7: 453-458.

4. Bech P, Rafaelsen OJ, Kramp $P$ et al. (1978). The mania rating scale: scale construction and inter-observer agreement. Neuropharmacology, 17: 430-431.

5. Young RC, Biggs JT, Ziegler E et al. (1978). A rating scale for mania: reliability, validity and sensitivity. British Journal of Psychiatry, 133: 429-435.

6. Secunda SK, Katz MM, Swann A et al. (1985). Mania. Diagnosis, state measurement and prediction of treatment response. Journal of Affective Disorders, 8: 113-121.

7. Brierley CE, Szabadi E, Rix KJ et al. (1988). The Manchester Nurse Rating Scales for the daily simultaneous assessment of depressive and manic ward behaviors. Journal of Affective Disorders, 15: 4554.

8. Altman EG, Hedeker DR, Janicak PG et al. (1994). The ClinicianAdministered Rating Scale for Mania (CARS-M): development, reliability, and validity. Biological Psychiatry, 36: 124-134.

9. Choca J, Bresolin L, Okonek A et al. (1988). Validity of the Millon Clinical Multiaxial Inventory in the assessment of affective disorders. Journal of Personality Assessment, 52: 96-105.

10. Bauer MS, Crits-Christoph P, Ball WA et al. (1991). Independent assessment of manic and depressive symptoms by self-rating. Scale characteristics and implications for the study of mania. Archives of General Psychiatry, 48: 807-812.

11. Braunig P, Shugar G \& Kruger S (1996). An investigation of the selfreport manic inventory as a diagnostic and severity scale for mania. Comprehensive Psychiatry, 37: 52-55.

12. Cooke RG, Kruger $S$ \& Shugar G (1996). Comparative evaluation of two self-report mania rating scales. Biological Psychiatry, 40: 279283.

13. Altman EG, Hedeker DR, Peterson JL et al. (1997). The Altman SelfRating Mania Scale. Biological Psychiatry, 42: 948-955.

14. Raskin A (1988). Discussion: recent developments in ascertainment and scaling of the BPRS. Psychopharmacological Bulletin, 24: 122124.
15. Overall JE \& Gorham D (1962). The Brief Psychiatric Rating Scale. Psychological Reports, 10: 799-812.

16. Guy W (1976). ECDEU Assessment Manual for Psychopharmacology. US Department of Health, Education, and Welfare publication ADM 76-338, National Institute of Mental Health, Rockville, MD, USA.

17. Goodwin FK \& Jamison KR (1990). Manic-Depressive IIIness. Oxford University Press, New York.

18. Marder SR (1995). Psychiatric rating scales. In: Kaplan HI \& Sadock BJ (Editors), Comprehensive Textbook of Psychiatry/VI. 6th edn. Williams \& Wilkins, Baltimore, MD, USA.

19. Kaplan HI \& Sadock BJ (1990). Definição de sinais e sintomas típicos de doença psiquiátrica. In: Kaplan HI \& Sadock BJ (Editors), Compêndio de Psiquiatria. 2nd edn. Artes Médicas, Porto Alegre, RS, Brazil.

20. American Psychiatric Association (1994). Diagnostic and Statistical Manual of Mental Disorders. 4th edn. American Psychiatric Association, Washington, DC, USA.

21. Del-Ben CM, Rodrigues CRC \& Zuardi AW (1996). Reliability of the Portuguese version of the structured clinical interview for DSM-III-R (SCID) in a Brazilian sample of psychiatric outpatients. Brazilian Journal of Medical and Biological Research, 29: 1675-1682.

22. Crippa JA, Sanches RF, Hallak JE et al. (2001). A structured interview guide increases Brief Psychiatric Rating Scale reliability in raters with low clinical experience. Acta Psychiatrica Scandinavica, 103: $465-470$.

23. Spitzer RL, Williams JBW, Gibbon M et al. (1990). Structured Clinical Interview for DSM-III-R - Patient Edition (SCID-P, version 1.0). American Psychiatric Press, Washington, DC, USA.

24. Bech P, Kastrup M \& Rafaelsen OJ (1986). Mini-compedium of rating scales for states of anxiety, depression, mania and schizophrenia with corresponding DSM-III syndromes. Acta Psychiatrica Scandinavica, 326 (Suppl): 7-37.

25. Zuardi AW, Loureiro SR, Rodrigues CRC et al. (1994). Estudo da estrutura fatorial, fidedignidade e validade da tradução e adaptação para o português da escala de avaliação psiquiátrica breve (BPRS) modificada. Revista da Associação Brasileira de PsiquiatriaAsociacion Psiquiatrica de la America Latina, 16: 63-68.

26. Streiner DL (1995). Learning how to differ: agreement and reliability statistics in psychiatry. Canadian Journal of Psychiatry, 40: 60-66.

27. Bartko JJ \& Carpenter Jr WS (1976). On the methods and theory of reliability. Journal of Nervous and Mental Disease, 163: 307-317. 
28. Williams JBW (1988). A structured interview guide for the Hamilton Depression Rating Scale. Archives of General Psychiatry, 45: 742747.

29. Lindström E, Wieselgren I-M \& Von Knorring L (1994). Interrater reliability of the Structured Clinical Interview for the Positive and Negative Syndrome Scale for Schizophrenia. Acta Psychiatrica Scandinavica, 89: 192-195.

30. Organização Mundial da Saúde (OMS; Coord.) (1993). Classificação de Transtornos Mentais e de Comportamento da CID-10: Descrições Clínicas e Diretrizes Diagnósticas. Artes Médicas, Porto Alegre, RS, Brazil.
31. Fristad MA, Weller EB \& Weller RA (1992). The Mania Rating Scale: can it be used in children? A preliminary report. Journal of the American Academy of Child and Adolescent Psychiatry, 31: 252-257.

32. Shugar G, Schertzer S, Toner BB et al. (1992). Development, use, and factor analysis of a self-report inventory for mania. Comprehensive Psychiatry, 33: 325-331.

33. Fristad MA, Weller RA \& Weller EB (1995). The Mania Rating Scale (MRS): further reliability and validity studies with children. Annals of Clinical Psychiatry, 7: 127-132. 


\title{
Appendix
}

\author{
Escala de Avaliação de Mania - eAM \\ Roteiro de entrevista para preenchimento da EAM
}

\section{Instruções}

A entrevista de avaliação para preenchimento da EAM é, a priori, não estruturada. As perguntas descritas aqui são APENAS um roteiro para que, na avaliação do paciente maníaco, nenhum dos itens da EAM deixe de ser avaliado. Portanto, o avaliador tem liberdade de realizar outras perguntas que julgar necessárias para avaliação de um determinado item, ou então, omitir outras, se o paciente (ou a observação direta) já tiverem oferecido informações sobre o item a que elas se referem.

As perguntas em parênteses devem ser feitas somente para complementar informações, podendo ser omitidas se o avaliador as julgar desnecessárias para a avaliação do item em questão.

O entrevistador deve julgar as condições do paciente no momento da entrevista, a partir do seu relato, mas privilegiando a observação direta.

Antes de iniciar a entrevista, deve-se observar no prontuário do paciente dados referentes ao seu nome, idade, endereço de moradia, data e hora de entrada no serviço, bem como dados referentes a suas condições sócio-culturais. Além disso, considerar relatos referentes a insônia, comportamento agressivo, agitação, irritabilidade e comportamento sexual inadequado nas últimas $48 \mathrm{~h}$. Essas informações são importantes para avaliação de itens como conteúdo do pensamento (neste caso sempre considerar a condição sóciocultural do paciente), irritabilidade, atividade psicomotora e interesse sexual, quando o paciente nega alterações. Nesses casos, confrontar gentilmente o paciente e observar suas respostas. Lembrar-se, contudo, que SEMPRE deve ser privilegiada a resposta do paciente e a observação direta.

A escala deve ser pontuada somente após o término da entrevista, e não no decorrer dela. Não é necessário que o paciente tenha todos os itens descritos numa determinada chave de gradação, mas apenas um, o que basta para que esta chave seja marcada. Considerar a alteração que permeia a maior parte da entrevista.

\section{Entrevista}

\section{Itens e perguntas-guia}

Qual o seu nome completo? E sua idade? Onde você mora? Com quem você mora? Está trabalhando atualmente? (Já trabalhou anteriormente? Em quê?)

\section{Insight}

Quanto tempo faz que você está aqui? Conte-me por que motivo você foi internado. Quando isso começou? O que aconteceu depois? O seu comportamento [jeito de agir ou de ser] tem sido diferente ultimamente? (Como?) (Você está doente? Quais são os sintomas da sua doença? Tem algum problema na cabeça? Você precisa de tratamento? Precisa tomar remédios?) [Confrontar se necessário]

\section{Sono}

Ultimamente, você tem sentido dificuldade para dormir? Quantas horas à noite você tem dormido? Quantas horas você normalmente costuma dormir? (Quantas horas a menos você tem dormido?) Ultimamente, você precisa de menos horas de sono para se sentir descansado e bem-disposto? [Confrontar se necessário]

\section{Irritabilidade}

Nos últimos dias você está impaciente ou irritável com as outras pessoas? (As pessoas tem deixado você nervoso?) Você está tão irritado [ou nervoso] que começa a brigar com as pessoas ou a gritar com elas? (Conseguiu manter o controle? Tolerou as provocações? Chegou a agredir alguém ou a quebrar objetos?) [OBSERVAR e confrontar se necessário]

\section{Atividade psicomotora}

Ultimamente, você tem se sentido mais disposto ou animado que o habitual? Você está se sentindo com muita energia? Sente-se inquieto ou agitado? Você sente vontade de fazer várias coisas ao mesmo tempo? [OBSERVAR e confrontar se necessário]

\section{Interesse sexual}

Você tem pensado muito em sexo? Tem tido algum tipo de comportamento sexual que não era habitual antes, ou que tem causado problemas com as outras pessoas? (Você tem estado muito "paquerador"? Alguém reclamou de algo que você tenha feito, neste 
sentido? Alguém reclamou do seu comportamento sexual?) [OBSERVAR e confrontar se necessário]

06. Fala

Ultimamente, você está mais falante que o normal? As pessoas falam que você está muito falante ou mais falante que o habitual? (As pessoas têm dificuldade de entender ou interromper você? As pessoas têm dificuldades em conversar com você?) [OBSERVAR]

\section{Conteúdo do pensamento}

Ultimamente, você tem tido pensamentos diferentes ou estranhos, ou idéias ou planos que antes não passavam pela sua cabeça? Quais seus planos para o futuro? (O que você tem vontade de fazer?) Nos últimos dias você tem se sentido com algum talento ou habilidade que a maioria das pessoas não tem? (Como você sabe disso?) Você acha que as pessoas têm inveja de você? Você acredita que tem alguma coisa importante para fazer no mundo? Você se considera famoso? Você tem alguma relação especial com alguém importante ou famoso? Você tem a impressão de que as outras pessoas estão falando ou rindo de você? (De que forma você percebe isso?) Você acha que tem alguém com más intenções contra você ou se esforçando para lhe causar problemas? (Quem? Por quê? Como você sabe disso?)

\section{Conteúdo do pensamento}

Você acredita que alguém ou alguma coisa fora de você esteja controlando seus pensamentos ou suas ações contra sua vontade? Você tem a impressão de que o rádio ou a televisão mandam mensagens para você? Você sente que alguma coisa incomum está acontecendo ou para acontecer? Você sente que tem alguma coisa incomum acontecendo no seu corpo ou cabeça?

\section{Humorelevado}

Ultimamente, como você se sente? Como tem estado o seu humor (alegre, triste, irritável?) (Se deprimido: Você acredita que pode melhorar?) Como este sentimento tem afetado o seu dia-a-dia? (Você está mais alegre [confiante ou otimista] que o habitual? Ultimamente, você está tão bem ou alegre, que as outras pessoas acham que você não está no seu normal? Você está tão alegre que isto lhe trouxe problemas?) [OBSERVAR]

Encerramento: Estas eram as perguntas que eu precisava fazer. Tem alguma que você acha importante dizer, que eu não perguntei, ou alguma coisa que gostaria de perguntar?

Obs.: Os itens 07, 09 e 10 da EAM são preenchidos exclusivamente a partir da observação direta.

\section{Item - definição}

01. Humor e afeto elevados

Este item compreende uma sensação difusa e prolongada, subjetivamente experimentada e relatada pelo indivíduo, caracterizada por sensação de bem-estar, alegria, otimismo, confiança e ânimo. Pode haver um afeto expansivo, ou seja, uma expressão dos sentimentos exagerada ou sem limites, associada a intensa relação com sentimentos de grandeza (euforia). O humor pode ou não ser congruente ao conteúdo do pensamento.

\section{Atividade motora - energia aumentada}

Este item compreende a psicomotricidade - e expressão corporal apresentada pelo paciente, incluindo a sua capacidade em controlála, variando desde um grau de normalidade, até um estado de agitação, com atividade motora sem finalidade, não influenciada por estímulos externos. O item compreende ainda o relato subjetivo do paciente, quanto à sensação de energia, ou seja, capacidade de produzir e agir.

\section{Interesse sexual}

Este item compreende idéias e/ou impulsos persistentes relacionados a questões sexuais, incluindo a capacidade do paciente em controlálos. O interesse sexual pode restringir-se a pensamentos e desejos não concretizados, em geral verbalizados apenas após solicitação, podendo chegar até a um comportamento sexual frenético e desenfreado, sem qualquer controle ou crítica quanto a riscos e normas morais.

\section{Graus}

(0) Ausência de elevação do humor ou afeto

(1) Humor ou afeto discreta ou possivelmente aumentados, quando questionado

(2) Relato subjetivo de elevação clara do humor; mostra-se otimista, auto-confiante, alegre; afeto apropriado ao conteúdo do pensamento

(3) Afeto elevado ou inapropriado ao conteúdo do pensamento; jocoso

(4) Eufórico; risos inadequados, cantando

(X) Não avaliado

\section{(0) Ausente}

(1) Relato subjetivo de aumento da energia ou atividade motora

(2) Apresenta-se animado ou com gestos aumentados

(3) Energia excessiva; às vezes hiperativo; inquieto (mas pode ser acalmado)

(4) Excitação motora; hiperatividade contínua (não pode ser acalmado)

(X) Não avaliado

(0) Normal; sem aumento

(1) Discreta ou possivelmente aumentado

(2) Descreve aumento subjetivo, quando questionado

(3) Conteúdo sexual espontâneo; discurso centrado em questões sexuais; auto-relato de hipersexualidade

(4) Relato confirmado ou observação direta de comportamento explicitamente sexualizado, pelo entrevistador ou outras pessoas

(X) Não avaliado 
04. Sono

Este item inclui a redução ou falta da capacidade de dormir, e/ou a redução ou falta de necessidade de dormir, para sentir-se bem-disposto e ativo.

05. Irritabilidade

Este item revela a predisposição afetiva para sentimentos/emoções como raiva ou mau-humor, apresentados pelo paciente frente a estímulos externos. Inclui baixo-limiar à frustração, com reações de ira exagerada, podendo chegar a um estado constante de comportamento desafiador, querelante e hostil.

06. Fala (velocidade e quantidade)

Este item compreende a velocidade e quantidade do discurso verbal apresentado pelo paciente. Inclui sua capacidade de percebê-lo e controlá-lo, por exemplo, frente a solicitações para que permaneça em silêncio ou permita que o entrevistador fale.

07. Linguagem - Distúrbio do pensamento

Este item refere-se a alterações da forma do pensamento, avaliado pelas construções verbais emitidas pelo paciente. O pensamento pode estar mais ou menos desorganizado, de acordo com a gravidade das alterações formais do pensamento, descritas a seguir:

- Circunstancialidade: fala indireta que demora para atingir o ponto desejado, mas eventualmente vai desde o ponto de origem até o objetivo final, a despeito da superinclusão de detalhes;

- Tangencialidade: incapacidade para manter associações do pensamento dirigidas ao objetivo - o paciente nunca chega do ponto inicial ao objetivo final desejado;

- Fuga de idéias: verbalizações rápidas e contínuas, ou jogos de palavras que produzem uma constante mudança de uma idéia para outra; as idéias tendem a estar conectadas e, mesmo em formas menos graves, podem ser difíceis de ser acompanhadas pelo ouvinte;

- Ecolalia consonante: repetição automática de palavras ou frases, com entonação e forma que produzem efeito sonoro de rima;

- Incoerência: fala ou pensamento essencialmente incompreensíveis aos outros, porque as palavras ou frases são reunidas sem uma conexão com lógica e significado.
(0) Não relata diminuição do sono

(1) Dorme menos que a quantidade normal, cerca de 1 hora a menos do que o seu habitual

(2) Dorme menos que a quantidade normal, mais que 1 hora a menos do que o seu habitual

(3) Relata diminuição da necessidade de sono

(4) Nega necessidade de sono

(X) Não avaliado

\section{(0) Ausente}

(2) Subjetivamente aumentada

(4) Irritável em alguns momentos durante a entrevista; episódios recentes (nas últimas 24 horas) de ira ou irritação na enfermaria

(6) Irritável durante a maior parte da entrevista; ríspido e lacônico o tempo todo

(8) Hostil; não cooperativo; entrevista impossível

(X) Não avaliado

(0) Sem aumento

(2) Percebe-se mais falante do que o seu habitual

(4) Aumento da velocidade ou quantidade da fala em alguns momentos; verborréico, às vezes (com solicitação, consegue-se interromper a fala)

(6) Quantidade e velocidade constantemente aumentadas; dificuldade para ser interrompido (não atende a solicitações; fala junto com o entrevistador)

(8) Fala pressionada, ininterruptível, contínua (ignora a solicitação do entrevistador)

(X) Não avaliado

(0) Sem alterações

(1) Circunstancial; pensamentos rápidos

(2) Perde objetivos do pensamento; muda de assuntos freqüentemente; pensamentos muito acelerados

(3) Fuga de idéias; tangencialidade; dificuldade para acompanhar o pensamento; ecolalia consonante

(4) Incoerência; comunicação impossível

(X) Não avaliado 


\section{Conteúdo}

Este item compreende idéias e crenças apresentadas pelo paciente, variando, de acordo com a intensidade, de idéias novas e/ou incomuns ao paciente, ideação supervalorizada (ou seja, crença falsa, intensamente arraigada, porém susceptível à argumentação racional), a delírios (crenças falsas, baseadas em inferências incorretas sobre a realidade, inconsistentes com a inteligência e antecedentes culturais do paciente, e que não podem ser corrigidas pela argumentação). Conteúdos comumente encontrados no paciente maníaco, incluem:

- Idéias místicas: de conteúdo religioso;

- Idéias paranóides: crença de estar sendo molestado ou perseguido;

- Idéias de grandeza: concepção exagerada da própria importância, poder ou identidade, incluindo posses materiais, qualidades incomuns e relacionamentos especiais com personalidades famosas ou entidades místicas;

- Idéias de referência: crença de que o comportamento dos outros tem relação consigo próprio ou de que eventos, objetos ou outras pessoas possuem um significado particular e incomum para si.

09. Comportamento disruptivo agressivo

Este item compreende a atitude e as respostas do paciente ao entrevistador e à situação da entrevista. $O$ paciente pode apresentarse desconfiado ou irônico e sarcástico, mas ainda assim respondendo aos questionamentos, ou então não cooperativo e francamente agressivo, inviabilizando a entrevista.

\section{Aparência}

Este item compreende a apresentação física do paciente, incluindo aspectos de higiene, asseio e modo de vestir-se.

11. Insight (discernimento)

Este item refere-se ao grau de consciência e compreensão do paciente quanto ao fato de estar doente. Varia de um entendimento adequado (afetivo e intelectual) quanto à presença da doença, passando por concordância apenas frente à argumentação, chegando a uma negação total de sua enfermidade, referindo estar em seu comportamento normal e não necessitando de qualquer tratamento.
(0) Normal

(2) Novos interesses e planos compatíveis com a condição sócio-cultural do paciente, mas questionáveis

(4) Projetos especiais totalmente incompatíveis com a condição sócio-econômica do paciente; hiper-religioso

(6) Idéias supervalorizadas

(8) Delírios

(X) Não avaliado
(0) Ausente, cooperativo

(2) Sarcástico; barulhento, às vezes, desconfiado

(4) Ameaça o entrevistador; gritando; entrevista dificultada

(6) Agressivo; destrutivo; entrevista impossível

(X) Não avaliado

(0) Arrumado e vestido apropriadamente

(1) Descuidado minimamente; adornos ou roupas minimamente inadequados ou exagerados

(2) Precariamente asseado; despenteado moderadamente; vestido com exagero

(3) Desgrenhado; vestido parcialmente; maquiagem extravagante

(4) Completamente descuidado; com muitos adornos e adereços; roupas bizarras

(X) Não avaliado

(0) Insight presente: espontaneamente refere estar doente e concorda com a necessidade de tratamento

(1) Insight duvidoso: com argumentação, admite possível doença e necessidade de tratamento

(2) Insight prejudicado: espontaneamente admite alteração comportamental, mas não a relaciona com a doença, ou discorda da necessidade de tratamento

(3) Insight ausente: com argumentação, admite de forma vaga alteração comportamental, mas não a relaciona com a doença e discorda da necessidade de tratamento

(4) Insight ausente: nega a doença, qualquer alteração comportamental e necessidade de tratamento

(X) Não avaliado 